\title{
The Representation of Social, Economic, Psychological, and Reproductive Health Condition of the Commercial Sex Workers Post-closing of the Dolly Complex in Surabaya
}

\author{
Danty Indra Puspitaningtyas'), Argyo Dermatoto²), Bhisma Murti1) \\ 1) Masters Program of Public Health, Sebelas Maret University, Surakarta \\ 2)Sociology Program, Faculty of Social and Political Science, Sebelas Maret University, Surakarta
}

\begin{abstract}
Background: Dolly was the biggest red light district in Southeast Asia with more than 1000 (a thousand) women working as commercial sex workers. Because the district imposed a very negative effect to the surrounding inhabitants especially to children, therefore red light district area of Dolly and Jarak which are located in residential area had to be closed. The quality of life of the residents especially the commercial sex workers was very much affected after the district was closed. The study aimed to understand the representation of the social, economic, psychological, and reproductive health condition after the Dolly district in Surabaya was closed.

Subject and Method: This was a qualitative descriptive study with phenomenology approach. This study was conducted in former red light districts of Dolly and Jarak in Surabaya from January 18-February 28, 2017. The informant of this study were commercial sex workers, former commercial sex workers, head of hamlet (RW), former pander of Dolly, Head of Civil Society Organization, healthcare workers, and Social Office of Surabaya City. The sampling technique used was snowball sampling, with in-depth interviews, observation, documentation study. The data were analyzed by interactive analysis model including data collection, data reduction, display and verification.

Results: The commercial sex workers characteristic prior and post closing of the district were around 28-43 years old, with elementary - senior high school educated. Most of the commercial sex workers were from outside the city with 1-5 customers/day. They charged Rp. 100-300 thousand (Dolly's commercial sex workers) per customer and Rp. 100-200 thousand/customer (Jarak's commercial sex workers). The representation of quality of life post-closing was poor, altered social condition, lack of interaction with others, the degradation of economic condition, poor psychological condition due to the economical problem, and reproductive health was less protected because they did not get regular examination like before the complex was closed.

Conclusion: The representation of quality of life in terms of the condition of social, economic, psychology, and reproductive health of the commercial sex workers post Dolly and Jarak closing were poor. Therefore, government intervention was very much needed to help improving the quality of life of the commercial sex workers.
\end{abstract}

Keywords: Commercial sex workers, social, economic, psychological, reproductive health.

\section{Correspondence:}

Danty Indra Puspitaningtyas. Masters Program of Public Health, Sebelas Maret University, Surakarta. Email: dantyindra@yahoo.com. Mobile: +6285732850663

\section{BACKGROUND}

Commercial sex worker is female who works to provide sexual activities in exchange for compensation from those who have used her service (Koentjoro, 2004).
In 2012, there were 47 red light districts in East Java. They were distributed in 33 cities/ regencies with 7,121 commercial sex workers and 1,031 panders working as an agent for the said commercial sex workers (Indra, 2012). Surabaya has the biggest number of commer- 
Journal of Health Promotion and Behavior (2017), 2(1): 77-87

https://doi.org/10.26911/thejhpb.2017.02.01.07

cial sex workers according to the statistical data report of Surabaya city official that in May 2014, there were 1,181 commercial sex workers and 300 panders working in Dolly and Jarak (Supomo, 2014).

Dolly or Gang Dolly was a name for for a red light district located in Kelurahan Putat, Kecamatan Sawahan, Surabaya, East Java, Indonesia, and it was the biggest one in Southeast Asia. Gang Dolly was already there during the Dutch era, i.e.: the $19^{\text {th }}$ century. National Geographic Indonesia (2014) stated that Dolly complex was initially a Chinese cemetery complex which included Girilaya, bordering the Moslem cemetery in Putat Gede. In the 1960 , some parts of the cemetery was turned into housing areas. In 1967, a former commercial sex worker with Philippines-Javanese blood named Dolly Khavit or known as Tante Dolly showed up. She was married to a Dutch sailor and started the first brothel on Jalan Kupang Gunung Timur I.

But, the government decided that Dolly and Jarak must be closed to provide better protection for children against the impact of the activities in the district which was located in a residential area (BBC Indonesia, 2014). Furthermore, it was also to stop the spreading of HIV/ AIDS especially in Surabaya which was raising every year. In 2013, there were 6,671 people with HIV/ AIDS and it is the highest in East Java (Beritasatu, 2014).

The closure of Dolly and Jarak district was in accordance to Peraturan Daerah Kotamadya Daerah Tingkat II Surabaya Number 7 Year 1999 Regarding the Prohibition of Building/Place Used to Conduct Prostitution and Enchanment to Commit the Act of Prostitution in Kotamadya Daerah Tingkat II Surabaya, stated about the prohibition to build a brothel or use a place to conduct prostitution.
There were negative and positive impact post Dolly and Jarak closing on June 18, 2014 for the commercial sex workers and the residents living in the vicinity. The impact highly influenced their living quality. Costanza et al., (2007) stated that the the living quality is the fulfillment or how far an individual or group views satisfaction or dissatisfaction in different domains in life. The method used to measure one's living quality is by using social indicator or quantitative economy to see how far human necessities are met. Other way is by using one's expression towards level of happiness, joy, or in other words, subjective welfare. On the other hand, objective is measuring living quality with social, economy, and health indicators.

Pratama (2016) states that the social condition of the people in the vicinity showed changes in terms of occupation and economically, there was a decline in the income earned by the people. Low educational level made it difficult for them to get jobs.

According to the study by Begum (2013) tentang "The Significance of Reguating Prostitution" regarding the importance of regulating prostitution. There are a lot of problems caused by prostitution, i.e.: drug abuse, violence, sexually transmitted disease outbreak, public unrest, organized crime, human trafficking, children prostitution, and exploitation. Because of these reasons, British government were required to undergo evaluation towards prostitution in terms of the programs and policies that would be applied to resolve the problems. England forbade street prostitution. They wanted prostitution to be regulated by the government so that any possible problems that may come up could be avoided and controlled. Besides that, there was also some effort in reduc- 
ing the number of commercial sex workers by helping individuals to leave the ring, for example by giving them other jobs or vocational training for them, providing homes to those who had lost their place, and rehabilitate those with drugs problem. Owing to that, the government, must improve the people's awareness on the danger of prostitution.

According to WHOQOL-BREF in Rapley (2003) there are four dimension in living quality which includes: physical health, psychological well-being, social interaction, and environment-related aspect. As for the factors influencing the quality of life are sex or gender, age, educational background, occupation, marital status, income, interaction with others, and standard reference (Nofitri, 2009).

PRECEDE PROCEED was effective if the problem is directly taken from the community or people, intervention planned sourced from the data, suitable and feasible ethnic intervention including continuous working program strategy depending on the feedback (Ibrahim et al, 2014). Green (2005); Fertman et al (2010) state that PRECEDE PROCEED directs the outcome which is living quality issue and not on the program input. Phase (1-5) focused on the program planning while phase (69) focused on the implementation and evaluation.

PRECEDE (Predisposing, reinforcing and enabling Construct in Educational/ Environmental Diagnosis and Evaluation). PROCEED (Policy, Regulatory and Organizational Constructs in Educational and environmental Development) (Green, 2005).

Due to that, the researchers was interested on analyzing the representation of living quality of the Commercial sex workers in the sense of social, economical, psychological, and health reproductive post closing the Dolly district in Surabaya.

This study was to find out the representation of living quality of the Commercial sex workers in the sense of social, economical, psychological, and health reproductive post closing the Dolly district

\begin{tabular}{l}
\hline SUBJECT AND METHOD \\
Research design \\
The study used the qualitative descriptive \\
study with phenomenology method. The \\
population used were former commercial \\
sex workers, or those who still actively \\
working in Dolly and Jarak in Surabaya. \\
Sampling technique was Snowball sam- \\
pling.
\end{tabular}

\section{Population and Sample}

Data sources used in the study, included 3 key Informants, 7 main informants, and 7 supporting informants.

The key informant were 1 head of RT/RW, 1 Dolly's former pander, and 1 CIVIL SOCIETY ORGANIZATION leader. Whereas, main informants were 4 former commercial sex workers, 3 active comercial sex workers; and supporting informant was a representative from the customer, 1 active pander, 1 Jarak's former pander, 1 middleman, 1 Civil Society Organization representative in Dolly and Jarak in Surabaya, 1 representative from Surabaya's social services, and 1 health-care personnel.

The location of the study was Dolly and Jarak in Surabaya and other places where the informant agreed to meet such as KAMI library, the pander's house, the commercial sex workers' boarding house, and restaurants to meet the informant.

The study was done in JanuaryFebruary 2017. The timing for the interview was as per the agreed appointment started from 9 AM- 9PM. 
Journal of Health Promotion and Behavior (2017), 2(1): 77-87

https://doi.org/10.26911/thejhpb.2017.02.01.07

The documentation used in this study included relevant documents to support the interview process. The document were: interview guidelines with open questions, recording apparatus to be used during the interview; books and supporting literature related to the material to be used during the interview and study.

\section{Data Analyzed}

Data collected using in-depth interview, observation, and documentation study.

The data gathered with in-depth interviews, observation, and documentation study. Data validity checking using triangulation technique by triangulating sources, method, and theory. Data analysis technique used was Miles and Huberman's interactive model consisted of data collection, data reduction, display, and verifycation.

\section{RESULTS}

Based on the result, it was gathered that from $15 \mathrm{RW}$ in Kelurahan Putat Jaya, 5 RW was used to Dolly and Jarak red light district which had 17 RT. RW used for the districts were RW 03, 06, 10,11, and 12.

Dolly district had 55 brothels but 7 was closed automatically thus only leaving 48 brothels in 3 RW $(6,10,12)$ and 5 RT (RW 6: RT 6, RW 10: RT 5 dan 6, RW 12: RT 4 dan 5), the rest were Jarak district. There were 230 brothels. As for the number of panders in Dolly and Jarak were 230 panders.

There were 558 commercial sex workers in Dolly and 463 in Jarak, in total there were 1021 commercial sex workers recorded. However, according to the Social Services, there were more than 1600 commercial sex workers recorded or not.

Dolly and Jarak were two red light districts adjacent to one another. Generally, Dolly is for the mid-high economic level while Jarak is mid-low economic level. It

is due to the price difference between the commercial sex workers in each district. Customers frequenting Dolly were usually of the Chinese-descent or foreigners visiting the country and curious about Dolly which was famous around the world, especially in Southeast Asia.

Dolly was the biggest red light district in Southeast Asia. It can be seen from the total transaction that could reach 2 billion rupiah in one night. Dolly brothels opened from 1-3PM then from $7 \mathrm{PM}-3 \mathrm{AM}$. While in Jarak, they opened from 10AM$1 \mathrm{AM}$ to serve customers who wanted to drink accompanied by the girls from the respective brothels. Should the customer wish to sleep with one the girls, they should be ready to serve. In Dolly, the commercial sex workers is only for sexual services, unlike in Jarak. Being a commercial sex worker in Jarak meant that you had to serve the karaoke guests and accompanied them drinking.

There were two kinds of panders in Dolly, the real pander and the "ID Card" pander. Real pander came from Surabaya and owned one of the brothels while "ID Card" pander was a pander from Surabaya but they did not own a brothel only that their ID card was lent to be the person responsible because one of the prerequisite requirement to be a pander was that he must be a Surabaya resident. "ID Card" pander might be in charge of more than 1 brothel, they also controlled the brothels under their wings on daily basis. They could earn Rp. 1,00o,00o/ day/ brothel excluding money for food, cigarettes, and other needs. Whereas the panders in Jarak were brothel owners that they managed themselves although the house they used were usually rented ones.

Almost 90\% of the commercial sex workers working in Dolly and Jarak were not from Surabaya. They came from re- 
gencies outside Surabaya such as Malang, Pekalongan, Tuban, Bojonegoro, Indramayu, and other places in Indonesia. Dolly's commercial sex workers would sit in the front seats and you could see them like an aquarium. They waited for any customers who would their service, while in front of the brothel there were busboys or middlemen trying to get customers for the girls.

The task of these busboys or middlemen was to get customers and lure them into the brothel. Sometimes, they would drink together with the potential customers while choosing any ladies sitting in front of them. Once the customer had made their mind, the busboy would take them to the rooms while keeping time because the rate in Dolly is per hour. The busboy would report it back to the front desk cashier the room number and the time. 5 minutes before the time was up, the middleman or the busboy would ask if the customer wanted more time or not because they will have to report it back to the front desk.

Different system applied in Jarak. In Jarak, the commercial sex workers found their own customers. They would sit in front of the house waiting for potential customers. Once they have one, then they would take them drinking, singing at the karaoke, and sleep with the customer should the customer wished it. When they were done, the customer paid the girls directly, while the money for drinking and room rental would be paid to their Madame or pander in the brothel. They could get Rp. 50,000/ hour to accompany drinking but they still have to share it with Madame/ pander. So, although the commercial sex workers accepted direct payment but they still have to give their money to their pander as per their tariff. They could withdraw their money once a month. However, should the customer paid them more, they got to keep the extra and still paid their own pander as per the agreed tariff. The cost of commercial sex workers in Jarak is about 80-150 thousand rupiah and they did not work on hourly basis. The customers themselves usually paid them 200-400 thousand rupiah.

The commercial sex workers in Dolly and Jarak did not get any days off. They would only allowed to rest for a week during their menstruation because one of the rules there was that they were not allowed to work when they were on their period until they were clean again. Such time would be used to visit their own hometown. Most the families did not know their real occupation was. They only knew that the ladies worked in Surabaya. .

Based on the character study of the commercial sex workers before Dolly and Jarak closing, the age group of the informants were around 28-43 years old. Based on the educational background, the lowest education of the commercial sex workers working in Dolly and Jarak was elementary school while the highest ones were of senior high school. According to their origin, the ladies working in Dolly and Jarak were mostly from outside Surabaya. The number of customers an active commercial sex worker could serve would be around 1-5 customers/ day, while for the former commercial sex workers before Dolly closure, they also had 1-5 customers/ day. Different tariff applied differed from one commercial sex worker to another. The difference was due to the brothel they worked for. In Dolly, the customers paid to the cashier at the front desk by the hour, while in Jarak, they paid directly to the commercial sex workers and there was no time limitation except for those wishing to spend the night. Commercial sex workers tariff in Dolly was around 100-300 
Journal of Health Promotion and Behavior (2017), 2(1): 77-87

https://doi.org/10.26911/thejhpb.2017.02.01.07

thousand rupiah/ hour, while in Jarak, they cost around 100-200 thousand rupiah per transaction regardless the time

The social condition in Dolly before the closing was that it was crowded with music from each corner of the district but post closure, the area became quiet like a dead town. The activities of the resident was just like any other kampong without anyone drunkenly getting in and out of any brothels, no more neat and prettily dressed ladies in front of the brothels waiting for customers or even inside the aquarium. Such activities might be gone forever or some might still do that but in hiding.

Viewed from the economic condition, they were collapsing, either from the commercial sex workers, the panders, or people living in the vicinity trying to hang on to Dolly and Jarak. They faced massive decline compared to before the closure of the district. The decline was about half to 2/3 compared to what they made before closure.

Post closing the district would definitely give different psychological effect such as anxiety, uneasiness. According to the study, the residents gave different reaction, some felt tranquility after the closure because there was not any sound pollution anymore, others prefer the time before the closure because of the money they received. After closure, no more customers, therefore income declined. There were those that felt upset, unhappy, even sad because of the closure because their livelihood depended on the district. Some were happy because they did not to lie and make up excuses to their families about their real jobs there. Some were also anxious because they were wedded and if any of their former customers greeted them it might cause their husbands to be jealous of them.
In regards to reproductive health of the commercial sex workers: menstruation, pregnancy, childbirth, post-partum, birth control, and STDs all of the comercial sex workers in this study did not have any disturbance in their menstrual cycle before or after district closure and only one who suffered from menstrual pain. Regarding pregnancy, almost all of the commercial sex workers and former commercial sex workers as the informant in this study had experienced pregnancy, childbirth, post-partum, before, while, and after they stopped working. There was only one former commercial sex worker who never experienced any of it.

As for birth control used by the commercial sex workers and former commercial sex workers working in Dolly and Jarak each used different kinds of method. There were monthly injection, quarterly injection, IUD, tubectomy, or only condoms as their protection. As for STDs, none of the informants of both active and former commercial sex workers ever had that. Only one had pathological vaginal discharge but only for a while due to rigid and controlled visit to the community health centre so that it could be treated immediately.

Besides routine check-ups, STDs prevention was also done by distributing condoms. Condoms were distributed in Putat Jaya community health centre or more appropriately Pustu working together with KPA Kota Surabaya. Outside that, condoms were also provided in each RW meeting hall for the commercial sex workers. They will get some condoms every time they checked themselves at the health centre. If they ran out, they could obtain it at the meeting hall. They have to take minimum 6 pcs/ week or maximum 8opcs (2 boxes)/ month. Post-closing, routine check-ups and condoms distribution were 
only available at the health centre. So, whether they wanted to check themselves or not is up to them now. Health-care facilities in Dolly and Jarak included community health centre, private doctor practice(DPP), and midwife clinics (BPM). There was one community health centre i.e.: Puskesmas Putat Jaya, and one helping clinic (Pustu). The commercial sex workers usually checked themselves at the helping clinic. There were also one private doctor practice and one midwife clinic.

\section{DISCUSSION}

The characteristic of the commercial sex workers working in Dolly and Jarak preclosure based on the informants were around 28-43 years old. This, however, different from what Kartono (2015) stated that the commercial sex workers are below 30 years old. This was contrary to what the researchers found that most of the commercial sex workers found by the researchers were above 30 years old. The data gathered by the CIVIL SOCIETY ORGANIZATIONs also stated that commercial sex workers under 30 years old were minorities in Dolly and Jarak. They were only found in New Barbara brothel.

In regards the educational background, the commercial sex workers working in Dolly and Jarak were at least was in the elementary school and at the maximum were in senior high school. Based on their origin, most of them were from outside Surabaya. From 7 informants, only one of them were from Surabaya.

Viewing at the phenomena above, poverty and ignorance could be the deciding factor for one to become a commercial sex worker, this could be seen from the characteristic of the commercial sex worker working in a brothel. Kartono (2015) states that these professional commercial sex workers from mid and low class are mostly from low economy and social level. They mostly did not have any specific skill besides the lack of education. Their only asset were their beauty and youth. Whereas according Regar and Kauripan (2016) low education factor influencing a woman's decision to be a commercial sex worker. Lack of education made it difficult for them to get proper job with decent wages to make up their living expenses.

The statement matched the result of the study that the commercial sex workers in Dolly and Jarak were mainly only finished their elementary school, junior, and senior high schools. From the lack of education, they lacked of skill to work in other field thus they decided to be a commercial sex worker.

This was supported by Shukla dan Mehrotra (2015), their study mentions that most of commercial sex workers that became their informant was around 25-30 years old, some were married and had children, illiterate, came in the slum or the villages, and was from low economy level. Their education mostly were only through junior to senior high schools.

Based on the number of customers in Dolly and Jarak, there was a decline because the number of commercial sex worker were also reducing and the customers were afraid and anxious about the raids done by Satpol PP. Now, they looked for safer entertainment centres.

The living quality of the residents especially the commercial sex workers around Dolly and Jarak also experienced changes. This can be viewed from their social, economic, psychological, and reproductive health condition. From the social condition, the residents can finally sleep quietly without any loud noises disturbing them. The children can play and study without any interference. The relationship among the commercial sex workers and 
Journal of Health Promotion and Behavior (2017), 2(1): 77-87

https://doi.org/10.26911/thejhpb.2017.02.01.07

the residents are also better because their places used to be guesthouses thus they have been familiar with each other. However, some still faced scoffing from people outside Dolly and Jarak, this might due to the commercial sex workers inability to place themselves when they were in the middle of the locals. In addition, the commercial sex workers who used to be organized in location, they are now scattered uncontrolled. They also used online system to run their business.

This was in accordance to the study done by Kurniawan (2010) who discovered that the closing of Silir red light district caused bigger social problems since the commercial sex workers that used to work in one centralized site was spread out onto the road caused the increasing on HIV/ AIDS spreading in Surakarta.

From the economy side, the closure caused crippling economy for the residents, all from the commercial sex workers themselves, the panders, and the people who depended themselves on Dolly and Jarak. They faced massive decline in their earning. They have not been able to start new business because of their lack of funding or even adding more debts to make ends meet. However, there are those who actually earned more by still working as a commercial sex worker. It was very easy for them to make money, thus spending it was easy too. However, now they felt difficulty in making money thus making them more careful with their spending.

The guilty and sinful feeling that these commercial sex workers had when they were still active. Such feeling happened not only because of their deviating sexual behavior but also because they had to keep on lying to their families about their real occupation. When the family called and asked about how they were, they had to run to hide in the bathrooms

because of the loud noises outside. They had to come up with excuses to convince their families. This made them felt uneasy, anxious, and feeling like they lived on an edge.

This was in accordance to what Rossler (2010) found about commercial sex workers mental health. The study shows that all of the 193 commercial sex workers suffered from heavy mental disturbances caused by the violence and workload they had to face.

Regarding the commercial sex worker's reproductive health, in terms of menstrual cycle, pregnancy, childbirth, postpartum, birth control, and STD, they were well but not fully protected. Before the closure, they were seriously monitored by the Putat Jaya community health centre togeher with CIVIL SOCIETY ORGANIZATIONs working in the red light district. They worked to get the commercial sex workers checked on weekly basis. Post closure, the commercial sex workers themselves that had to take care of their own reproductive health. If they had high awareness in their condition, they would go and have themselves checked without any personnel or CIVIL SOCIETY ORGANIZATION pushing them to do it.

This phenomenon was different from the study done by (2014) which mentioned that there is social inequality faced by female migrant worker in the prostitution world. The foreign commercial sex workers are on higher risk to get ill due to their living and working condition as commercial sex workers, inequality in health services, and lack of social networking making it difficult for them to get proper healthcare in Spain. In Dolly, however, every one got the same treatment, even those who were on the highest risk.

The living quality of the commercial sex workers post closing very much de- 
pends on the commercial sex workers themselves which can be influenced by several factors. They are predisposing, reinforcing, and enabling factors.

Predisposing factor is the economic inability. Most of the commercial sex workers in Dolly and Jarak came from poor families and some of them were single parents with children to support that made them hang on to their job despite the difficulties they faced post closure, which was the raids by Satpol PP. Furthermore, there was no economical preparation prior the closing to allow them to find an alternative to make ends meet. The money they had when Dolly was still on was spent lavishly. The current conditions very much influence their psychological condition.

Whereas the reinforcing factor that influence the living condition of commercial sex workers was that because the district is closed, they can choose whether they want to quit or continue their life as commercial sex workers. The ambiance of the district was not the same anymore. The activities had turned to normal, children could play freely without any disturbances. Working commercial sex workers would do their business in hiding; they would even use the online system to run their business with the help of the middlemen. They would set up an appointment in a hotel or an inn that was a brothel. Before closure, there were some social activities for the commercial sex workers such as prayer, green walk, or even vocational training. However, since the closure, such activities are unavailable for them.

The closure lead to decreasing income of commercial sex workers, thus made them difficult to meet their needs. This made them sad, frustrated, anxious, even stressed out. Their reproductive health condition had become uncontrolled unlike before closure. There used to be regular check up that the commercial sex workers had to undergo and after the closing they do not have that anymore, they have to go and check themselves individually. This generates uncontrolled spreading of HIV/AIDS and STDs.

The enabling factor influencing their living quality is that the lavish lifestyle that they could not leave behind. They were familiar with the luxurious life because they could buy whatever they liked thus making it difficult for them to leave prostitution. They also had large debts with big interest to the local loan sharks.

To help overcoming the problems post-closure in regards to the living quality of the people especially the commercial sex workers, the government haS to lend a hand to finish this. As stated on the study by Kangiwa in 2015, it is the most effective way to reduce prostitution. The force that encourages prostitution is the profit earned from the business. Prostitution itself has its positive and negative impact. In order to reduce the number of commercial sex workers, the government of Nigeria provides job opportunities, public enlightenment, reformation and rehabilitation programs, providing public facilities for recreation, sports, and cultural activities. They also provide formal education for the illiterate and unskilled commercial sex workers and reproductive health education in schools curriculum.

\section{REFERENCE}

Begum N (2013). The Significance of Regulating Prostituition. Internet Journal of Criminology. Internet Journal of Criminology.

Beritasatu.com. (2014). Jumlah Penderita HIV/AIDS di Surabaya Meningkat. http://www.beritasatu.com/kesra/18 8087penderita-hivaids-di surabaya.- 
Journal of Health Promotion and Behavior (2017), 2(1): 77-87

https://doi.org/10.26911/thejhpb.2017.02.01.07

html. Diunduh pada tanggal 4 November 2016.

Costanza R, Brendan F, Ali S, Beer C, Bon L, Boumans R, Danigelis N (2007). Quality of Life: An approach Integrating Opportunitis, Human Needs, and Subjective well-being. Ecological Economics 267-276. doi:10.1016/j.ecolecon.2006.02.023.

Fertman CI, Allensworth DD (2010). Health Promotion Programs From Theory To Practice.United State of America: Library of Congress cataloging- in- Publication Data. http://samples.sainsburysebooks.co.uk/978 0470590171_-sample_417772.pdf. Diakses tanggal 6 Desember 2016.

Green WI (2005). Health Program Planning an A Diagnostic Approach Fourth Edition. California: McGrawHill Companies.

Ibrahim S, Sidani S (2014). Community Based HIV Prevention Intervention in Developing Countries: A Systematic Review. Hindawi Publishing Corporation Advances in Nursing, 1-11.

Kangiwa AG (2015). The Socio-Economic Factors And Effects Of Prostitution In Nigeria. European Journal of Research in Social Sciences. 3(5).

Kartono K (2015). Patologi Sosial jilid 1. Jakarta: PT Raja Grafindo Persada.

Koentjoro (2004). On The Spot: Tutur Sang Pelacur. Yogyakarta: Tinta.

Kurniawan D. (2010). Pelacuran di Surakarta (Studi Kasus Pasca Penutupan Resosialisasi Silir 1988-2006). Skripsi. digilib.uns.ac.id. Diunduh pada tanggal 2 November 2016.

Lestari S (2014). Menjelang Penutupan Lokalisasi Gang Dolly. Wartawan BBC Indonesia. http://www.bbc.com/indonesia/berita_indonesia/20 14/o6. diunduh pada tanggal 4 November 2016.
National Geographic Indonesia (2014). Legenda Sang Tante Dolly. Ada Beragam Kisah Terkait Awal Berdirinya Dolly. http://nationalgeographic.co.id/berita/. Diakses pada tanggal 17 November 2016.

Nofitri (2009). Gambaran Kualitas Hidup Penduduk Dewasa pada Lima Wilayah di Jakarta. Fakultas Psikologi Universitas Indonesia.

Pemkot Daerah Tingat II Surabaya. Peraturan Daerah Kotamadya Daerah Tingkat II Surabaya Nomor 7 Tahun 1999 tentang Larangan Menggunakan Bangunan/ Tempat untuk Perbuatan Asusila serta Pemikatan untuk Melakukan Perbuatan Asusila. http://jdih.surabaya.go.id/pdf/perda _375.pdf. Diunduh pada tanggal 4 November 2016.

Pratama I (2016). Dampak Penutupan Lokalisasi Bangunsari Terhadap Kondisi Sosial Ekonomi Masyarakat Bangunsari Krembangan, Surabaya. Swara Bhumi 1(2). Diakses dari http://ejournal.unesa.ac.id/. pada 2 Desember 2016.

Rapley M (2003). Quality of Life Research: A Critical Introduction. London: Sage Publication, Inc.

Regar PM, Kauripan JK (2016). Pengetahuan Pekerja Seks Komersial (PSK) dalam Mencegah Penyakit Menular Kelamin di Kota Manado. Jurnal Holistik, IX(17).

Rios A (2014). Female Migration and Health in Different Prostitution Scenarios in the Province of Almeria, Spain. Procedia-Social and Behavioral Sciences 132 (2014): 582-588.

Rolles W, Koch U, Lauber C, Hass A-K, Altwegg M, Ajdacic-Gross V, Landolt K (2010). The Mental Health of Female Sex Workers. Acta Psychiatr 
Puspitaningtyas et al./ The representationof Social, Economic, Psychological

Scand 2010: 1-10. DOI: 10.1111/ j.16000447.2009.01533.x.

Shukla A, Mehrotra D (2015). Background Characteristics of Female Sex Workers. International Journal of Yoga and Allied Sciences, 4(1).
Supomo, Tim Pemkot Surabaya (2014). Data Pekerja Seks Komersial dan Mucikari di Lokalisasi Dolly dan Jarak. Surabaya, Tidak Diterbitkan. 